\title{
IMPLEMENTASI NILAI DASAR PERJUANGAN HIMPUNAN MAHASISWA ISLAM TERHADAP PEMBINAAN KADER HMI KOTA PALEMBANG
}

\author{
Heryati \\ Pendidikan Sejarah, FKIP Universitas Muhammadiyah Palembang \\ heryatisejarah15@gmail.com \\ Yusinta Tia Rusdiana \\ Pendidikan Sejarah, FKIP Universitas Muhammadiyah Palembang \\ yusintat@yahoo.com
}

\begin{abstract}
Abstrak
Tulisan ini bertujuan untuk mengungkap pemikiran-pemikiran Cak Nur yang mempengaruhi kader HMI Cabang Palembang, khususnya pemikirannya yang terdapat di dalam NDP HMI yang telah ia susun. Penelitian ini merupakan kajian lapangan (field research) yang terfokus mengkaji implementasi NDP HMI dalam pembinaan kader pada HMI Cabang Palembang dengan menggunakan metode deskriptif kualitatif dengan paradigma induktif. Metode dan paradigma tersebut dipilih atas pertimbangan terhadap analisis masalah penelitian yang menuntut sejumlah informasi dari bawah berdasarkan prinsip-prinsip penelitian kualitatif. Pendekatan kesejarahan, sosiologis, dan fenomenologis menjadi pilihan agar tujuan penelitian dapat tercapai dengan baik. Adapun jenis data dalam penelitian ini adalah kualitatif-kuantitatif. Hasil dalam penelitian ini adalah pertama, NDP pada awalnya merupakan kertas kerja PB HMI periode 1966-1969 yang disusun oleh Cak Nur. NDP HMI merupakan cerminan pemikiran keislaman, kemanusiaan dan keindonesiaan khas HMI. Kedua, NDP bagi kader HMI cabang Palembang merupakan identitas kedirian kader atau jati dirinya. HMI cabang Palembang memberikan porsi yang sama bagi setiap kader untuk memperoleh pengajaran dan pendidikan tentang NDP secara berjenjang; mulai dari Masa Perkenalan Calon Anggota (MAPERCA), Latihan Kader I (LK I), LK II, LK III, sampai tingkatan yang paling tinggi, yaitu Training Instruktur NDP. Ketiga, Cak Nur, sebagai figur organisatoris maupun intelektual bagi kader HMI cabang Palembang memberikan pengaruh yang cukup signifikan, khususnya pemikiran-pemikirannya yang tertuang di dalam NDP HMI.
\end{abstract}

Kata kunci: HMI, Cak Nur, LK

\section{Abstract}

his paper is required to reveal the thoughts of Cak Nur who plays HMI cadres Palembang Branch, especially the thoughts that are in the HMI NDP he has compiled. This study is a field study (field research) focused on assessing the implementation of NDP HMI in cadre development on HMI Palembang Branch by using qualitative descriptive method with inductive paradigm. The methods and paradigms are selected on the basis of the analysis of the research issues required from the bottom of the information based on qualitative research principles. Historical, sociological, and phenomenological approaches are an option for the purpose of research can be achieved well. The type of data in this study is qualitative-quantitative. The results of this study are first, the NDP on the content is the working paper of PB HMI period 1966-1969 compiled by Cak Nur. NDP HMI is a reflection of Islamic thinking, humanity and keindonesiaan typical HMI. Secondly, the NDP for the HMI cadres of Palembang branch is the identity of the cadres or their identity. HMI Palembang branch provides equal portion for each cadre to get teaching and education about NDP in stages; starting from the Introduction of Prospective Members (MAPERCA), Kader I Training (LK I), LK II, LK III, to the highest level, the NDP Instructor Training. Thirdly, Cak Nur, as an organizational and intellectual figure for the HMI cadres of Palembang branch has significant influence, especially the thoughts that are contained in NDP HMI.

Keywords: HMI, Cak Nur, LK 


\section{PENDAHULUAN}

Dalam konteks personifikasi nilai dasar institusional yang dimaksud disinyalir juga berlaku di lingkungan $\mathrm{HMI}$ (Himpunan Mahasiswa Islam) Cabang Kota Palembang. Organisasi HMI sendiri seperti yang dimaklumi adalah sebuah organisasi mahasiswa Islam yang cukup tua di Indonesia, yang berdiri di Yogyakarta pada tahun 1947. (Sitompul, 2007: 56).

Berbicara tentang kiprah sebuah organisasi yang cukup tua, seperti halnya Himpunan Mahasiswa Islam (HMI), adalah tak terlepas dari kontribusi pemikiran para tokoh intelektual yang menjadi aktor utama organisasi masing-masing. Dalam lingkup HMI salah seorang tokoh utama yang dimaksud adalah Nurcholis Madjid. Tak dapat dipungkiri bahwa corak berpikir keislaman Nurcholis Madjid (selanjutnya akan disebut Cak Nur), dianggap cukup berpengaruh terhadap pembentukan karakter berpikir keislaman $\mathrm{HMI}$, baik secara institusional maupun personal.

Dalam lingkungan HMI Cak Nur menjadi tauladan. Para kadernya tak jarang mengutip pemikiranpemikirannya. Karya-karya Cak Nur seperti menjadi referensi wajib bagi mereka, sehingga tulisan, perkataan dan gagasan-gagasan mereka memiliki kemiripan intelektual yang nyaris seragam. Sebagai rujukan, Cak Nur memang menempati posisi dominan dibanding dengan tokoh-tokoh lainnya dan ini menyebabkan generasi muda setelah Cak Nur dikritik sebagai generasi yang tidak mandiri dan sangat bergantung pada sosok Cak Nur (Sitompul, 2007 : 63).

Fakta-fakta ini kiranya cukup untuk menyebut bahwa Cak Nur berjasa dalam meletakkan dasar-dasar perubahan bagi masyarakat. Dalam konteks pengkaderan, Cak Nur berjasa bagi pembentukan bakat-bakat intelektual muda di lingkungan kampus dan organisasi HMI. Pengaruh Cak Nur semakin terasa ketika selama masih aktif di HMI, Cak Nur menyusun sebuah dokumen sebagai bagian dari silabus perkaderan HMI, khususnya menyangkut materi keislaman yang saat itu dianggapnya kurang mendapat tempat yang memadai ketimbang materi-materi organisasi dan politik. Materi yang disusun Cak Nur ini dikenal dengan "Nilai-Nilai Dasar Perjuangan, selanjutnya disingkat NDP HMI." (Azhari Akmal Tarigan, 2007: 23).

Dalam tulisannya, Cak Nur mengisahkan bahwa semula NDP ini ingin dinamakan Nilai Dasar Islam (NDI), akan tetapi kesan klaimnya cukup tinggi, seolah-olah hanya inilah nilai Islam, maka ini dihindari dan kemudian disesuaikan dengan aktifitas HMI yakni sebagai organisasi mahasiswa. 
Selanjutnya Cak Nur menemukan sebuah buku yang ditulis oleh Willy Eicher dengan judul The Fundamental Values and Basic Demand of Democratic Sosialism (Nilai-Nilai Dasar dan TuntutanTuntutan Asasi Sosialisme Demokrat). Dari buku inilah Cak Nur terispirasikan untuk mengambil istilah "Nilai-Nilai Dasar". Sedangkan kata perjuangan diambil dari buku Syahrir yang berjudul Perjuangan Kita, maka jadilah NDP tersebut. (Nurcholis Madjid, 1990 : 43). Konsep ini kemudian dibawah ke Kongres HMI ke-IX periode 1966-1969 di Malang untuk diformalkan menjadi dokumen resmi organisasi. (ART HMI 2006: 6). Menurut Cak Nur, bahwa selain keindonesiaan dan kemahasiswaan, kualifikasi HMI sebagai gerakan pemuda adalah keislaman, maka selain harus tampil sebagai pendukung nilai-nilai keindonesiaan dan kemahasiswaan, HMI juga harus tampil sebagai pendukung nilai-nilai keislaman. Sekalipun dukungan pada nilai-nilai keislaman itu tetap dalam format yang tidak dapat dipisahkan dari keindonesiaan dan kemahasiswaan. Artinya, penghayatan HMI pada nilai-nilai keislaman itu tidak dapat lepas dari lingkungan keindonesiaan (antara lain demi efektifitas dan fungsionalitas keislamannya itu sendiri), dan juga tidak terlepas dari nilai kemahasiswaan (yaitu suatu pola penghayatan keislaman yang lebih cocok dengan kelompok masyarakat yang menikmati hak istimewa sebagai anggota civitas academica. (Madjid, 1997 : 89).

Secara umum pengaruh pemikiran keislaman Cak Nur terhadap HMI tampak di dalam dokumen NDP yang disusun Cak Nur dalam beberapa bab di antaranya; Dasar-dasar Kepercayaan, Pengertian Dasar Tentang Kemanusiaan, Ketuhanan Yang Maha Esa dan Masalah Kemanusiaan, Kebebasan Manusia (Ikhtiar) dan Keharusan Universal (Takdir), Individu dan Masyarakat, Keadilan Sosial dan Keadilan Ekonomi, dan IImu Pengetahuan. (Dokumen PB HMI). Yang membuat Cak Nur termotivasi untuk menyusun NDP HMI adalah untuk memberi panduan bagi kader HMI agar bisa memahami Islam dengan baik dalam dimensi ruang dan waktu dan menjadi acuan untuk memahami Islam secara lebih komprehensif dan rasional. (Azhari Akmal Tarigan, 2007: 2-3).

Kemudian dari periode ke periode, dokumen NDP itu sejak adanya hingga sekarang, selain berfungsi sebagai tafsir asas ke-Islam-an HMI. NDP juga menjadi rujukan penting dalam setiap proses pengkaderan HMI, khususnya dalam pemberian materi-materi keislaman. Bahkan untuk memahami NDP ini, dalam pengkaderan HMI, dialokasikan waktu khusus untuk menjabarkan NDP secara utuh dan komprehensif. Dalam NDP HMI tidak ditemukan bahasan tentang ajaran-ajaran yang bersifat 
teknis fiqhiyah, namun lebih memuat nilai-nilai yang bersifat universal, maka NDP menjadi sangat sulit dipahami. Bukan hanya itu, karena pembahasaannya yang sulit dipahami dan ini menurut Cak Nur disengaja karena NDP dimaksudkan sebagai kumpulan nilai, maka penguraian/penjelasan NDP dalam proses pengkaderan di setiap HMI cabang pun menjadi sangat beragam. (ART HMI 2006).

Pada hakikatnya semangat kelahirkan NDP HMI paralel dengan semangat kelahiran $\mathrm{HMI}$ itu sendiri, hanya saja dalam kasus NDP, Cak Nur sangat berperan dalam mengkonseptualisasikannya secara lebih sistematis, utuh dan komprehensif. (Sitompul, 2007: 179-185). Dari penjelasan tersebut, dapatlah dikatakan bahwa NDP HMI yang disusun Cak Nur mendapat tempat yang cukup kuat bagi pembentukan karakter berpikir keislaman HMI. Hal ini menandakan bahwa pemahaman keislaman HMI cukup kuat dipengaruhi oleh sosok Cak Nur.

\section{METODE PENELITIAN}

Jenis penelitian yang digunakan adalah penelitian lapangan (field research) yang menggunakan metode deskriptifkualitatif dengan paradigma induktif. Dalam hal ini penulis pilih atas dasar pertimbangan terhadap analisis masalah penelitian yang menuntut sejumlah informasi dari bawah berdasarkan prinsip-prinsip penelitian kualitatif (Moeloeng, 2001: 5). Pendekatan penelitian mengunakan pendekatan kesejarahan (historis approach), pendekatan sosiologis dan pendekatan fenomenologis.

Sumber data yang digunakan dalam penelitian ini adalah Sumber Data Primer yang berupa data yang langsung dikumpulkan dari buku-buku atau dokumen-dokumen yang diterbitkan oleh HMI, seperti Nilai-Nilai Dasar Perdjuangan (1971), Kumpulan Materi dan Puisi (tanpa tahun terbit), dan dari responden yang terdiri dari pembina, pengurus dan anggota kader HMI Cabang Palembang, yang merupakan informasiinformasi yang berkaitan langsung dengan objek kajian sedangkan, data sekunder dalam penelitian ini seperti buku yang ditulis oleh Victor Immanuel Tanja (1991), Himpunan Mahasiswa Islam, buku yang ditulis oleh Suharsono (1997), HMl; Pemikiran dan Masa Depan, buku yang ditulis oleh Muhammad Hari Zamhari (2004), Agama dan Negara; Analisis Kritis Pemikiran Nurcholish Madjid, dan buku yang ditulis oleh Nurcholish Madjid (1987), Islam Kemodernan dan Keindonesiaan.

Teknik sampling yang digunakan dalam penelitian ini adalah purposive sampling (cuplikan). Purposive sampling digunakan untuk pertimbangan dapat memilih informan secara selektif dengan pertimbangan tertentu. Pertimbangan 
tertentu ini, misalnya orang tersebut yang dianggap paling tahu tentang apa yang diharapkan, sehingga akan memudahkan peneliti menjelajahi obyek/situasi sosial yang diteliti (Sugiyono, 2012: 300).

Teknik pengumpulan data mengunakan observasi berperan serta (participant observation), wawancara mendalam (in depth interview) dan dokumentasi (Sugiyono, 2012: 308-309). Teknik analisis data dilakukan dengan menggunakan model analisis interaktif. Dalam model analisis ini terdapat tiga komponen yang harus dipahami oleh para peneliti yaitu reduksi data, sajian data dan penarikan simpulan/ verifikasi (Miles \& Huberman, 1992: 16).

\section{HASIL DAN PEMBAHASAN}

\section{Pemikiran Nurcholish Madjid Dalam Nilai Dasar Perjuangan HMI}

Pada masa kepemimpinan Nurcholis Madjid, HMI secara nasional mampu menghasilkan suatu dasar asasi yang kukuh bagi organisasinya terutama untuk menjawab dengan tepat masalahmasalah pembaharuan keagamaan di dalam umat. Dalam beberapa kalimat yang dirumuskan dan disusun paling baik ialah Nilai Dasar Perjuangan (NDP) yang dihasilkan selama kongres HMI ke-9 pada tahun 1969. Sejak itulah kedudukan keagamaan dan ideologi HMI secara resmi dapat dirumuskan oleh Nurcholish
Madjid yang dibantu oleh Sakib Mahmud dan Endang Saefudin Ansari.

Adapun pokok-pokok pemikiran Cak Nur dalam NDP HMI akan diuraikan berikut ini:

\section{Tentang Dasar Kepercayaan}

Diakui sebagai kenyataan, bahwa kepercayaan atau iman adalah hakiki bagi peradaban dan tak terelakkan bagi manusia. Tetapi walaupun keimanan ini memberikan kebenaran, namun ia pun melahirkan tradisi-tradisi demikian membelit masyarakat dan dengan tegas menolak perubahan. Oleh karena itu, sayang sekali bila harus melawan kemajuan. Tampaknya jalan keluar dari problema ini ialah bahwa bagaimanapun masyarakat harus membebaskan tradisitradisi yang menghambat kemajuan dan kembali kepada keimanan semula yang ditegaskan oleh Allah atau petunjuk sejati. Kalimat syahadat yang pertama"Tidak ada Tuhan melainkan Allah"mengandung pengertian baik penyangkalan maupun pengecualian. Kalimat “Tak ada Tuhan”, menyangkali semua kepercayaan palsu; sedangkan kalimat "melainkan Allah" adalah pengecualian yang diperuntukkan bagi kepercayaan yang benar terhadap Allah. (NDP HMI 1971, hal. 5-7). Maksudnya, dengan menyangkali semua kepercayaan palsu, manusia membebaskan dirinya sendiri dari ikatan tradisi. Sedangkan dengan memberikan pengecualian bagi 
yang benar, manusia menyerahkan dirinya kepada Allah, itulah arti hakiki Islam.

\begin{tabular}{lcr}
\multicolumn{3}{c}{ Manusia memiliki bermacam- } \\
macam jalan, termasuk pendekatan \\
terhadap Tuhan secara intuitif, secara \\
ilmiah, secara menyejarah, secara \\
pengalaman; & tetapi & dalam
\end{tabular}
keterbatasannya manusia tidak dapat dengan kesanggupannya sendiri benarbenar menangkap hakikat Yang Maha Esa itu. Untuk ini manusia memerlukan wahyu Tuhan yang tidak diberikan kepada setiap umat manusia, tetapi hanya kepada orang-orang suci tertentu yang terpilih sebagai rasul (utusan) dan nabi. Garis sejarah para rasul dan nabi sepanjang zaman merentang dari nabi Adam kepada Nuh kepada Ibrahim kepada Musa kepada Isa, putra Mariam, memuncak dalam diri Muhammad SAW nabi dan rasul terakhir sepanjang masa. (NDP.HMI, $1971: 7$ ).

Dengan demikian, dari pemikiran Cak Nur yang tertuang dalam NDP di atas dapat dikatakan, bahwa kehidupan yang baik adalah yang disemangati oleh iman dan ilmu. Bidang iman dan pencabangannya menjadi wewenang wahyu, sedangkan ilmu pengetahuan menjadi wewenang manusia untuk menguasai dan mengumpulkan kehidupan dunia ini. Ilmu itu meliputi tentang alam dan manusia (sejarah), dan untuk memperoleh ilmu pengetahuan tentang nilai kebenaran sejauh mungkin, manusia harus melihat alam dan kehidupan ini sebagaimana adanya tanpa melekatkan kepadanya kualitas-kualitas yang bersifat Ketuhanan. Sebab, seperti diungkapkan sebelumnya, alam diciptakan dengan wujud yang nyata dan objektif sebagaimana adanya. Alam tidak menyerupai Tuhan dan Tuhan pun tidak sama dengan alam. Sikap yang mempertuhankan dan mensakralkan haruslah ditujukan kepada Tuhan semata; Tuhan yang Maha Esa. Landasan berpikir seperti ini hendaknya dimiliki oleh setiap kader HMI.

\section{Tentang Masalah Kemanusiaan}

Sebagai khalifah Tuhan di muka bumi, manusia akan cenderung kepada kebenaran. (NDP.HMI,1971 : 11). Hati nuraninya merupakan pemancar bagi keinginannya untuk melakukan kebenaran. Fitrahnya itu jugalah yang menyebabkan manusia berbeda dari makhluk-makhluk yang lain. Menuruti perintah-perintah hati nuraninya itu, menyebabkan manusia hidup sesuai dengan fitrahnya dan oleh karenanya ia menjadi benar dengan sendirinya. Manusia yang benar ialah mereka yang menangkap makna hidup dengan mengerjakan amal saleh atau perbuatanperbuatan yang berkebaikan. Dengan demikian, kebahagiaan akan dapat ditemukan di dalam langkah maju yang dilaksanakan dengan perbuatanperbuatan baik. Berangkat dari pemikiran di atas, dapat dikatakan 
bahwa Cak Nur sebenarnya menginginkan kader HMI mencapai tingkatan manusia sejati (insan kamil), yang mana kegiatan mental dan fisiknya merupakan suatu keseluruhan. Kerja jasmani dan kerja rohani bukanlah dua kenyataan yang terpisah. Malahan dia tidak mengenal perbedaan antara kerja dan kesenangan, kerja baginya adalah kesenggangan dan kesenangan ada dalam dan melalui kerja. Dia berkepribadian, merdeka, memiliki dirinya sendiri, menyatakan ke luar corak perorangannya dan mengembangkan kepribadian dan wataknya secara harmonis. Dia tidak mengenal perbedaan antara kehidupan individual dan kehidupan komunal, tidak membedakan antara perorangan dan sebagai anggota masyarakat, hak dan kewajiban serta kegiatan-kegiatan untuk dirinya adalah juga sekaligus untuk sesama umat manusia.

\section{Tentang Masalah Kemerdekaan} Manusia

Mengenai masalah kemerdekaan, dikatakan bahwa tidak mungkin kejujuran tanpa kemerdekaan. Kehidupan memiliki dua sisi, fanâ' (binasa) dan baqâ' (abadi). Dalam hal yang pertama, orang harus melakukan perbuatan baik dan siap mempertanggungjawabkan apa yang telah dilakukannya, baik sebagai pribadi maupun sebagai anggota masyarakat. (NDP HMI, $1971: 13$ ).
Dalam segi yang kedua, orang tak berkesempatan lagi untuk melakukan perbuatan baik, hanyalah menunggu peradilan Tuhan sendiri sebagai pribadi. Pendek kata, manusia dilahirkan seorang diri, menjadi anggota masyarakatnya, dan sesudah mati ia seorang diri pula berhadapan dengan Tuhannya. Oleh karena itu, kepribadian manusia merupakan kenyataan dasar perikemanusiaan, yang di atasnyalah nilai-nilai kemanusiaan berpangkal. Sebagai pribadi, manusia harus memikul tanggung jawab atas perbuatannya; maka dari itu kemerdekaan pribadi adalah hak utama dan asasi bagi manusia. Sebagai makhluk sosial, di lain pihak, maka harus mempergunakan kemerdekaannya itu tanpa merugikan manusia lain. (NDP HMI, 1971 : 13-14).

Langkah yang Dilakukan HMI Cabang Palembang dalam

Mengimplementasikan NDP pada HMI Palembang

NDP bagi kader HMI cabang Palembang khususnya dipandang dari empat aspek; pertama, sebagai substansi spirit ajaran Islam Khas HMI. Kedua, sebagai komposisi dan formulasi ideal dan utuh dari makna iman, ilmu dan amal. Karena itu NDP dapat dipahami sebagai sarana pokok dan utama untuk mewujudkan kemanusiaan dan kemasyarakatan universal. Ketiga, sebagai paham sekaligus keyakinan berpikir HMI yang dapat menjadi landasan dan energi 
utama bagi kader $\mathrm{HMl}$ dalam mewujudkan misinya. Keempat, NDP sebagai landasan etis dan normatif setiap kader HMI untuk mencapai tujuannya. (Hambali Yusuf, Wawancara, 7 April 2017).

Setiap kader HMl cabang Palembang harus memiliki kesiapan mental untuk mendalami NDP secara Netral, obyektif, dinamis, istiqamah, dan komitmen dalam kebenaran. Obyektif adalah keyakinan mengenai kebenarannya. Sikap obyektif akan nampak pada keyakinan, kebenaran dan sikap subyektif itu. Karena suatu kepastian bahwa obyektifitas itu subyektif. Obyektifitas bukan lawan subyektivitas melainkan pasangan. Kajian NIK/NDP di dalamnya sangat filosofis, maka dalam mempelajarinya harus dilandasi semangat keterbukaan, kejujuran dan dinamis. Terbuka tidak saja mau berdialog dengannya tetapi juga mau melepas dahulu segala cara menyakini Al-Qur'an yang telah dimiliki. Jujur berarti harus mau mengakui dan menerima kebenaran apabila potensi kesadarannya telah dapat menerima dan mengakui. Dinamis, di dalam mempelajari NIK/NDP berarti mencari kebenaran. Dengan demikian menuntut proses yang terus menerus karena kebenaran yang ditemukan itu sebenarnya hanya sementara.

Setelah NIK/NDP dipahami oleh seorang kader dan diterima sebagai cara meyakini (berkeyakinan), maka akan ditemukan nilai-nilai. Bagi $\mathrm{HMI}$, nilai-nilai yang ditemukan dengan metode NIK (Nilai-Nilai Islam) inilah yang selalu diperjuangkan sebagai misinya. Sehingga mission HMI akan selalu merujuk kepada Nilai-Nilai Kader ini yang bersumber dari NDP HMI. (Budi Riyoko, Wawancara, 21 April 2017).

NDP sangat penting, karena $\mathrm{HMl}$ bukan organisasi massa, tetapi organisasi kader. Dengan demikian, kader wajib memiliki karakter nilai-nilai yang integral. Sehingga nantinya diharapkan apapun status dan peran kadernya di arena pengabdian tetap mewarnai aktivitasnya dengan nilai-nilai keislaman, kemanusiaan dan keindonesiaan. Tegasnya, kualitas kader HMI cabang Palembang terletak pada amal salehnya via proses perkaderan lewat materi NDP. (M. Hasyim Zamzam, Wawancara, 28 April 2017).

NDP mengajarkan kepada kader HMI, bahwa proses mencari kebenaran itu tidak boleh berhenti. Karena kebenaran yang diperoleh manusia sesungguhnya adalah kebenaran yang bersifat relatif. Kebenaran yang absolut itu hanya ada pada Tuhan. Oleh sebab itu segala upaya untuk memahami ajaran agama secara argumentatif, harus dihargai. Aliran-aliran keagamaan yang muncul dalam Islam, baik yang sesat atau tidak, semuanya harus dipahami sebagai bagian dari usaha untuk 
menemukan kebenaran yang hakiki. Oleh sebab itu, tidak sepantasnya atas nama otoritas semu, upaya pencarian kebenaran itu dihentikan sama sekali. Kecuali kita memang meyakini kebenaran yang sudah ada adalah mutlak benar. (Budi Riyoko, Wawancara, 28 April 2017).

Kader $\mathrm{HMI}$ cabang Palembang hendaklah memiliki kemampuan menguasai nilai-nilai dalam NDP, meskipun harus diakui setiap kader berbeda-beda tingkat pemahaman dan pengamalannya, semuanya sangat terkait dengan kesempatan dan keseriusan dalam mengikuti pelatihan kader, baik formal maupun informal. Nilai-nilai keislaman, kemanusiaan, dan ke-indonesian yang tetuang dalam NDP mestinya menjadi cerminan pribadi pengurus dan kader HMI cabang Palembang. (Mgs. Anwar Husin Umrie, Wawancara, 25 Mei 2017).

Senada dengan yang diungkapkan Mgs. Anwar Husin Umrie, Hambali Yusuf mengatakan; sebagai kader bangsa dan kader umat wajib bagi semua kader HMI cabang Palembang paham akan nilai-nilai yang terdapat dalam NDP HMI, lalu menjiwai semua nilai-nilai dasar tersebut dan mengaplikasikannya dalam kehidupan sehari-hari. (Hambali Yusuf, Wawancara, 19 Mei 2017).

Pengaruh Nurcholish Madjid Terhadap Pembinaan Kader HMI Cabang Palembang
Nurcholish Madjid atau akrab dipanggil Cak Nur, bagi kader HMI cabang Palembang adalah sosok organisator yang menjadi teladan. Di samping itu, ide-ide pembaharuan keagamaannya sangat menginspiratif, terutama yang tertuang dalam NDP HMI. (Budi Riyoko, Wawancara, 19 Mei 2017). Hal ini menunjukkan bahwa hingga dewasa ini sosok Cak Nur masih eksis di hati para kader HMI cabang Palembang, sehingga figurnya menjadi teladan, ide-idenya menginspiratif dan pemikiranpemikirannya menjadi motor pergerakan.

Kader HMI cabang Palembang dalam memperjuangkan nilai kebenaran senantiasa didasari oleh NDP HMI, setiap gerakan yang dilakukan bertujuan untuk mengoreksi dan memperbaiki kondisi masyarakat, bangsa dan negara. Oleh karena itu, menurut Budi Riyoko (Wawancara, 20 Nopember 2011), ukuran kemurnian gerakan yang dilakukan oleh para kader HMI adalah sebagai berikut:

1. Memperjuangkan kebenaran dan kepentingan rakyat

2. Merupakan gerakan moral yang terlepas dari segala kepentingan

3. Bersifat netral terhadap semua golongan.

HMI cabang Palembang dalam merealisasikan NDP memposisikan diri sebagai gerakan moral, maka ada beberapa hal yang menjadi landasan 
pergerakan. Pertama, gerakan yang dilakukan oleh para kader HMI cabang Palembang harus mampu membangkitkan kesadaran masyarakat untuk menolak ketidakadilan, dilandasi oleh idealisme, etika, moralitas dan aspirasi masyarakat. Kedua, harus menjadi kesadaran bagi HMI cabang Palembang bahwa aspirasi masyarakat yang mereka bawa lewat aktivitas demonstrasi hendaklah dilakukan dengan damai. (Hambali Yusuf, Wawancara, 26 Mei 2017). Hal tersebut paling tidak telah mencerminkan nilai kemanusiaan, kemerdekaan dan keadilan sosial yang diyakini dan diaktualisasikan para kader HMI cabang Palembang.

Salah satu wujud usaha yang dilakukan para kader HMI cabang Palembang yang didasari oleh nilai-nilai keislaman dan keindonesiaan yang tertuang dalam NDP, yaitu mengabdikan diri mereka terhadap semua permasalahan yang dihadapi oleh umat Islam dan masyarakat dalam wilayah Palembang khususnya dan Sumatera Selatan pada umumnya. Bentuk pengabdian tersebut adalah sebagai upaya untuk mendampingi umat dan masyarakat mengatasi persoalan yang dihadapinya, dalam hal ini para kader HMI cabang Palembang telah melakukan fungsinya sebagai social control. (Tamami Takrori,Wawancara, 29 Mei 2017).

Masih menurut Takrori, bentuk realisasi gerakan kontrol sosial yang dilakukan dapat diketahui dalam tiga hal. Pertama, dalam bentuk intelektual HMI. Misalnya usaha pencerdasan umat dan masyarakat, rumusan ide dan konsep serta perbaikan kualitas dan mampu mengatasi persoalan yang dihadapi masyarakat. Kedua, pengorganisasian umat dan masyarakat. Misalnya usaha untuk membangun dan memperbaiki sistem keagamaan, sosial, ekonomi, politik, pendidikan dan budaya umat dalam masyarakat. Ketiga, melakukan nahy al-munkar (pencegahan terhadap hal-hal negatif) yang akan merusak tatanan umat dan masyarakat (Tamami Takrori, Wawancara, 29 Mei 2017). Hal ini jika direalisasikan menjadi usaha nyata, paling tidak telah mencerminkan nilai keadilan sosial dan keadilan ekonomi, nilai individu dan masyarakat serta nilai manusia dan ilmu pengetahuan.

Dalam menerapkan nilai-nilai dasar perjuangan $\mathrm{HMI}$, para kader $\mathrm{HMI}$ telah melakukan berbagai usaha pergerakan dalam kehidupan bermasyarakat, berbangsa dan bernegara. Di antaranya adalah para kader HMI cabang Palembang membantu masyarakat untuk memperoleh keadilan yang dirugikan oleh kebijakan pemerintah daerah dalam kasus penimbunan rawa yang dilakukan oleh pengusaha mengakibatkan banjir. (Hambali Yusuf, Wawancara, 2 Juni 2017). Hal ini menunjukkan adanya 
realisasi dari pemahaman kader terhadap pentingnya nilai keadilan sosial dalam NDP.

Kader HMI cabang Palembang sejak tahun 1966 dan 1970 telah memulai fungsinya sebagai kontrol sosial, yaitu mengadakan aksi demonstrasi anti perjudian, pada saat itu perjudian di kota Palembang sudah sangat marak dan meresahkan masyarakat, sehingga para kader HMI cabang Palembang melakukan gerakan anti judi dengan menjalin kerjasama dengan berbagai elemen organisasi seperti Serikat Mahasiswa Muslim Indonesia (SEMMI), Ikatan Mahasiswa Muhammadiyah (IMM), Keluarga Mahasiswa Islam (KMI). Dengan gerakan tersebut berhasil meminimalisir perjudian yang begitu menjamur dan meresahkan masyarakat Palembang. Usaha yang telah dilakukan oleh para kader HMI cabang Palembang mengenai masalah perjudian ini paling tidak telah mengindikasikan adanya penerapan nilai individu dan masyarakat serta nilai ketuhanan dan kemanusiaan.

Pada tahun 1977 HMI cabang Palembang melakukan aksi penolakan pembangunan gereja di atas pemakaman umat Islam yang terletak di Jalan Letkol Iskandar 15 Ilir. Gerakan ini diikuti beberapa elemen organisasi kemahasiswaan lainnya seperti Pergerakan Mahasiswa Islam Indonesia (PMII), Pemuda Muslim Indonesia (PMI), Pelajar Islam Indonesia (PII) dan Ikatan
Pelajar Muhammadiyah (IPM). Usaha yang telah dilakukan oleh para kader HMI ini mencerminkan penerapan nilai keadilan sosial.

Pada tahun 1996-1997, ketika perjudian mulai marak lagi di Palembang, maka HMI cabang Palembang berada di garda terdepan sebagai penentang perjudian saat itu yang sangat marak di komplek Ilir Barat, Perintis Kemerdekaan, dan Sayangan yang merupakan titik-titik sentral lokasi perjudian. HMl cabang Palembang juga membuka posko pengaduan masyarakat terkait masalah perjudian dan kemaksiatan. Hasilnya diperoleh beberapa laporan masyarakat terkait dengan hal tersebut, dengan demikian teridentifikasi titik-titik sentral perjudian dan prostitusi di Palembang. (Budi Riyoko, Wawancara, 17 Juni 2017). Hal tersebut memperlihatkan konsistensi kader HMI cabang Palembang dalam penerapan nilai-nilai indivu dan masyarakat agar terciptanya tatanan masyarakat yang lebih baik.

Pada tahun 1998 merupakan puncak gerakan mahasiswa dengan didengungkan gerakan reformasi yang berhasil mengakhiri masa Orde Baru yang ditandai lengsernya Presiden Suharto. HMI cabang Palembang turut berperan aktif dalam gerakan menuntut reformasi dengan sikap-sikap mendukup reformasi. Mengawal terus-menerus proses reformasi serta penerapannya di Wilayah 
Sumatera Selatan. HMI cabang Palembang senantiasa memantau dan mengawal serta menuntut agar proses pemilihan Pemerintah daerah harus bersih dari segala bentuk KKN. (Budi Riyoko, Wawancara, 17 Juni 2017). Usaha-usaha yang dilakukan oleh para kader HMI cabang Palembang dalam hal menciptakan tata pemerintahan yang baik, serta senantiasa mengawal proses reformasi dalam segala bidang merupakan salah satu bentuk pengejawantahan pemahaman mereka terhadap nilai-nilai individu dan masyarakat serta nilai-nilai keadilan sosial. Dalam aktifitas pergerakannya, para kader HMI cabang Palembang senantiasa berkoordinasi dengan lembaga-lembaga yang terkait seperti DPRD, aparat kepolisian dll,. (Hambali Yusuf, Wawancara, 14 Oktober 2011). Hal ini menunjukkan adanya komitmen kader $\mathrm{HMI}$ cabang Palembang dalam menerapkan nilai-nilai individu dan masyarakat.

Dengan demikian pemikiranpemikiran Cak Nur secara umum mempengaruhi intelektualisme kader HMI cabang Palembang, dan khususnya yang telah tertuang di dalam NDP HMI, hal itu nampak dari berbagai usaha pergerakan yang telah dilakukan oleh para kader HMI cabang Palembang dalam hal hidup bermasyarakat, berbangsa dan bernegara.

\section{PENUTUP}

\section{Simpulan}

Dari uraian terdahulu dan sekaligus sebagai jawaban terhadap permasalahan yang telah dirumuskan, maka dapat disimpulkan sebagai berikut:

1. NDP HMI secara historis muncul karena kebutuhan terhadap buku saku organisasi. NDP ini mencakup tema pokok; NDP HMI secara historis muncul karena kebutuhan terhadap buku saku organisasi. NDP ini mencakup tema pokok; pertama, tentang Dasar-Dasar Kepercayaan; kedua, mengenai PengertianPengertian Dasar tentang Kemanusiaan; ketiga, mengenai Universalisme Islam dan Kebebasan Berusaha; keempat, mengenai Ketuhanan yang Maha Esa dan Perikemanusiaan; Kelima, mengenai Individu dan Masyarakat; keenam, tentang Keadilan Sosial dan Keadilan Ekonomi; ketujuh, tentang Kemanusiaan dan Ilmu Pengetahuan. Atau secara sederhana dapat dikatakan pemikiran Cak Nur dalam NDP HMI itu merupakan cerminan pemikiran keislaman, kemanusiaan dan keindonesiaan.

2. NDP bagi kader HMI Cabang Palembang adalah dasar dalam perjuangan hidup, baik dalam berorganisasi, bermasyarakat, dan bernegara. Dalam rangka mencapai tingkat implementasi NDP bagi kader, HMI Cabang Palembang melaksanakan 
aktivitas-aktivitas pembinaan secara berjenjang dan berkelanjutan. Hal ini dilakukan agar setiap kader memperoleh kesempatan mengkaji, memahami, menjiwai dan mengimplementasikannya. Adapun aktivitas-aktivitas pembinaan tersebut dimulai dari Masa Perkenalan Calon Anggota (MAPERCA), Latihan Kader I (LK I), LK II, LK III, sampai tingkatan yang paling tinggi, yaitu Training Instruktur NDP.

3. Cak Nur, sebagai figur organisatoris maupun intelektual bagi kader HMI cabang Palembang memberikan pengaruh yang cukup signifikan. Tidak mengherankan bila ia masih tetap diidolakan oleh para kader HMI cabang Palembang dengan tidak menafikan tokoh-tokoh lainnya, seperti Deliar Noer, Akbar Tanjung dan lain-lain. Di samping itu juga, forum-forum kajian Cak Nur juga banyak mendapat perhatian dari kader-kader HMI cabang Palembang, seperti kajian tentang pluralisme (kalimat as-sawa'; semua agama itu baik), demokrasi, kesetaraan gender dan seterusnya. Satu hal lagi yang menarik dari yang telah disebutkan, bahwa bagi kader yang akan mengikuti Pelatihan Ideo-politik NDP disyaratkan membaca paling tidak 15 buku karya Cak Nur. Semua itu bisa menjadi indikator-indikator betapa masih berpengaruhnya Nurcholis

Madjid baik secara personal maupun intelektual bagi kader $\mathrm{HMI}$ cabang Palembang secara umumnya, dan khususnya pemikiran-pemikirannya yang tertuang di dalam NDP HMI yang senantiasa dikaji dan diaktualisasikan oleh kader HMI cabang Palembang dalam kehidupan bermasyarakat, berbangsa dan bernegara. Di antara bukti nyata adanya penerapan NDP HMI oleh kader HMI cabang Palembang yaitu melaksanakan berbagai gerakan seperti demonstrasi anti judi dan prostitusi, menyuarakan aspirasi masyarakat yang dirugikan oleh kebijakan pemerintah daerah dalam hal penimbunan rawa yang mengakibatkan kerugian karena banjir, menentang pembangunan gereja di atas lokasi pemakaman masyarakat muslim, menuntut reformasi pada masa Orde Baru, mengawal proses reformasi dalam segala aspek birokrasi pemerintahan, mengawal pemilukada agar terbebas dari segala bentuk KKN. Dari semua usaha pergerakan yang dilakukan oleh kader HMI cabang Palembang paling tidak telah mencerminkan nilai-nilai yang terkandung NDP HMI, di antaranya adalah nilai individu dan masyarakat, nilai ketuhanan dan perikemanusiaan, serta nilai keadilan sosial.

\section{Saran}


Peneliti perlu untuk memberikan beberapa saran berkenaan dengan hasil penelitian tersebut. Dalam membaca sejarah HMI cabang Palembang belum ada buku khusus tentang sejarah dan pergerakan HMI cabang Palembang, yang ditemukan di lapangan masih berbentuk dokumen-dokumen laporan para pengurus HMI Cabang Palembang terdahulu.

Penulis menyarankan kepada para kader di HMI Cabang Palembang, dan khususnya pengurus cabang agar melakukan usaha-usaha untuk menerbitkan buku tentang sejarah dan pergerakan HMI Cabang Palembang. Hal ini dipandang penulis perlu untuk dilakukan supaya para kader mendatang tahu tentang sejarah wadahnya. Kedua, Secara umum memang kader di lingkungan $\mathrm{HMI}$ kota Palembang mengerti betul tentang NDP HMI serta menjiwai dan berusaha untuk mengaktualisasikan nilai-nilai yang terkandung di dalamnya dalam kehidupan berorganisasi, bermasyarakat, berbangsa dan bernegara, akan tetapi ada juga yang belum mampu untuk memperoleh pemahaman yang baik sehingga berdampak pada tidak tercerminnya NDP tersebut dalam kpribadiannya sebagai kader HMI.

\section{DAFTAR PUSTAKA}

Abdullah, M. Amin. 2006. Islamic Studies di Perguruan Tinggi: Pendekatan Integratif-Interkonektif, Cet I; Pustaka Pelajar, Yogyakarta.
Abdurrahman. 1999. Metode Penelitian Sejarah, Logos, Jakarta

Arikunto, Suharsismi. 1993. Prosedur Penelitian, Suatu Pendekatan, Cet IX; Rineka Cipta, Jakarta.

Bakri, Syamsul, Mudhofir dan Mudhofir Abdullah 2004. Jombang-Kairo, Jombang-Chicago: Sintesis Pemikiran Gus Dur dan Cak Nur dalam Pembaruan Islam di Indonesia, Tiga Serangkai, tt.
Departemen Pendidikan dan Kebudayaan. 1991. Kamus Besar Bahasa Indonesia. Jakarta: Balai Pustaka

Dokumen PB HMI tetang NDP HMI

Lexy J Moleong. 2010. Metodologi Penelitian Kualitatif. Bandung: Remaja Rosdakarya.

Miles B. Matthew dan Huberman A. Michael. 1992. Analisis Data Kualitatif: Buku Sumber tentang Metode-metode Baru. terjemahan: Tjetjep Rohendi Rohidi. Jakarta: UI Press.

Madjid, Nurcholis. 1990. "Gagasan dan Latar Belakang Perumusan NDP HMI", dalam, HMI Menjawab Tantangan Zaman, Gunung Kulabu, Jakarta.

Madjid, Nurcholis. 1992. Islam Doktrin dan Peradaban, Sebuah Telaah Kritis Tentang Masalah Keimanan, Kemanusiaan dan Kemodernan, Cet I; Paramadina, Jakarta.

Madjid, Nurcholis. 1997. Tradisi Islam, Peran dan Fungsinya Dalam Pembangunan di Indonesia, Cet I; Paramadina, Jakarta.

Madjid, Nurcholis. 2002. Masyarakat Religius Membumikan Nilai-Nilai Islam dalam Kehidupan Masyarakat, Cet II; Paramadina, Jakarta.

Madjid, Nurcholis. 1998. Islam Kemodrenan dan Keindonesiaan, Cet, XI; Mizan, Bandung.

Madjid, Nurcholis. 1998. Dialog Keterbukaan, Artikulasi Nilai Islam 


$$
\begin{aligned}
& \text { dalam Wacana Politik } \\
& \begin{array}{l}
\text { Kontemporer, Cet I; Paramadina, } \\
\text { Jakarta. }
\end{array}
\end{aligned}
$$

Sugiyono. 2012. Metode Penelitian

Pendidikan: Pendekatan

Kuantitatif, Kualitatif, dan R\&D.

Bandung: Alfabeta.

Sitompul, Agus Salim. 1999. “Dokumen Landasan Perjuangan HMl dalam Lintasan Sejarah", dalam, Menuju Masyarakat Cita: Refleksi atas Persoalan-Persoalan Kebangsaan, Badko HMI Malirja, tt.

Tarigan, Azhari Akmal. 2007. Islam Mazhab HMI, Tafsir Tema Besar Nilai Dasar Perjuangan (NDP), Cet; I, GP Press Group, Jakarta.

\section{Arsip Dan Wawancara}

Arsip-arsip pengurus $\mathrm{Hmi}$ cabang Palembang

Wawancara-wawancara pribadi 
Implementasi Nilai Dasar Perjuangan Himpunan..., Heryati \& Yusinta Tia Rusdiana, 29-44 